\title{
Transforming Local Government with Innovative Leadership: an Evidence from Banyuwangi, East Java
}

\author{
Budi Wiriyanto \\ Bali Post Journalist \\ budi.banyuwangi@gmail.com \\ Rachmat Hidayat \\ University of Jember \\ rachmat.hidayat@unej.ac.id \\ Ketut Mastika \\ University of Jember \\ i.ketut.mastika@unej.ac.id
}

\begin{abstract}
Innovation in local government is mandatory to provide certainty of services in the public sector. Success in public sector innovation cannot be separated from innovative leadership which is a determining factor in organizational progress. (Sudaryono, 2014). This is in line with the many innovations that were rolled out in Banyuwangi Regency, East Java. Since 2010, Banyuwangi Regency has developed quite rapidly, marked by many innovations under the leadership of Regent Abdullah Azwar Anas, better known as Regent Anas. One of the most prominent innovations is innovation in popularizing the tourism sector in Banyuwangi Regency and the public service sector. Public service innovations that are able to provide convenience for the community one of them, the use of digital technology in the administration of public administration. The success of making various public sector innovations, in 2018, Banyuwangi District received an award as the Innovative District in the Innovative Government Award (IGA) from the Ministry of Internal Affairs of the Republic of Indonesia (Ministry of Internal Affairs).
\end{abstract}

Keywords : Leasdership, Innovation, Innovative Leadership, Local Government

\section{INTRODUCTION}

Leadership is the key to success in organizational development, both in the private and public sectors (Sudaryono, 2014). In the public sector, leaders, especially regional heads are demanded to be able to innovate, thus making changes in the regions they lead. This innovation by the head of the region was demonstrated by Banyuwangi Regent Abdullah Azwar Anas. Since 2010, Banyuwangi Regency has developed quite rapidly. Development, both physical and non-physical, is felt very well by the community. One of the most prominent non-physical developments is innovation in popularizing tourism in the national arena and the public service sector. Public service innovations that are rolled out are able to provide convenience for the community. One of them, the use of digital technology in the administration of public administration. From various public sector innovations, in 2018, Banyuwangi was awarded as the Innovative Regency 
in the Innovative Government Award (IGA) from the Ministry of Home Affairs of the Republic of Indonesia (Ministry of Home Affairs). (sindonews.com, 2018).

One of the most prominent public sector innovations in Banyuwangi Regency is the Public Service Market. This innovation became a pioneer in Indonesia. The form of innovation, renovating the traditional market in Genteng District became a center for public services. (detik.com, 2019). This public sector innovation is a continuation of innovation in the form of the first Public Service Mall at the district level launched by Regent Abdullah Azwar Anas in 2017.

In addition there are innovations in the tourism sector that are quite popular and are able to lift the name Banyuwangi in the national and international arena. (coverage6, 2018). Tourism innovation is poured in the form of the Banyuwangi Festival. Since the introduction of tourism innovation in the form of the Banyuwangi Festival, tourist visits to the Banyuwangi Regency have increased. The sharpest increase began to be felt since 2016 which reached 4.2 million more people in one year. This condition has an impact on economic development in Banyuwangi Regency. The economic development of Banyuwangi Regency is illustrated in the following table:

Table 1.1 Increase in district GRDP in the Tapal Kuda Area

\begin{tabular}{|c|c|c|c|c|c|c|c|}
\hline \multirow{2}{*}{ Regent } & \multicolumn{7}{|c|}{ GRDP (Ribu Rupiah) } \\
\cline { 2 - 8 } & 2010 & 2011 & 2012 & 2013 & 2014 & 2015 & 2016 \\
\hline Bayuwangi & 20822.3 & 23579.4 & 26743.4 & 29928.7 & 33607 & 37751.3 & 41468.2 \\
\hline Bondowoso & 11533.2 & 12850.6 & 14214.3 & 15665.2 & 17272.3 & 19030 & 20727.3 \\
\hline Lumajang & 14140.1 & 15865.8 & 17470.6 & 19180.1 & 21417.7 & 23701.3 & 25769.6 \\
\hline Situbondo & 13051.2 & 14590.4 & 16277 & 18030.6 & 20028.3 & 22093 & 24177.3 \\
\hline Probolinggo & 13674.2 & 15230.8 & 16837.2 & 18545.9 & 20444.9 & 22523.9 & 24430.2 \\
\hline
\end{tabular}

(BPS Jatim,2016)

From the innovations rolled out by Regent Abdullah Azwar Anas, a number of questions emerged. The fundamental question revolves around in detail how the innovation process emerged and was carried out well, then the leadership style used to realize innovation.

\section{A. Leadership and Innovation in Public Sector}

In organizations, both private and public, leadership plays an important role. In the hands of leaders, organizations can develop or vice versa. Therefore, leadership is a complex phenomenon of social interaction. Sudaryono (2014: 8). Kouzez and Posner (2007), described leadership as the art of mobilizing others so that they want and want to struggle to pursue shared aspirations. Similar explained Wahjosumijo (2002), leadership is the process of influencing the activities of a person or group in an effort to achieve organizational goals. In line with this opinion, Sondang (2003) said that leadership is the core of management, namely as a driving force for resources and tools in the organization. Every leader has a leadership character called leadership style. Sudaryono (2014: 200) defines leadership style as an embodiment of the behavior of a leader regarding his ability to lead. The embodiment, according to him, usually forms a 
certain pattern or form. The Dharma (2004) describes that the leadership style is the pattern of behavior exhibited by someone when he tries to influence others. Furthermore, Nawawi (2003) defines leadership style as the behavior or method chosen and used by leaders in influencing the thoughts, feelings, attitudes and behavior of members of the organization or subordinates.

Innovative from the basic word of innovation. In Indonesian dictionary, innovative is defined as something that is introducing new things or renewals. (kbbi.web.id, 2019). Yogi cited (2007) cited Noor (2017: 80) defines innovation as coming from Latin, innovare, which means changing something into something new. Furthermore Manuel (2006) defines innovation as changing something into something new. In line with this, Ancok (2012: 34) defines innovation as a work of new ideas that can be applied in human life. Furthermore, Mckeown (2008) argues that innovation is a form of change from something, whether incremental (little by little), or radical change.

\section{B. Transformasional, Transaksional and Phronesis Leadership}

Innovative leaders have characteristics closely related to three theories about leadership, respectively: transformational, transactional leadership and phronesis. Transformational leadership is defined as a leader whose attention is devoted to the problems faced by followers and the development needs of each of his followers by providing encouragement and enthusiasm to achieve goals. (Sudaryono, 2014: 205). Keegan and Hartogg (2004) explain that transformational leadership is related to strong self-identification, the creation of a shared vision for the future and the relationship between leaders and followers based on something more than just giving rewards to be obedient. Lale and Arzu (2009) describe the characteristics of transformational leadership styles that correlate with the emergence of innovation in organizations.

In terms of politics that triggers innovation, transactional leadership is closely related to transformational leadership. Judge and Piccolo (2004) describe that in the concept of political leadership, there are links between transformational and transactional leadership. Similar as explained by Sudaryono (2014: 2003), transactional leadership is leadership that emphasizes the tasks carried out by his subordinates. Transactional leadership is more emphasized on the role of leader as manager.

A leader, when carrying out his role in moving the organization will face a variety of conditions that can not be predicted in advance. Among them, a surprising problem, ambiguous to the dilemma that arises from within and outside the organization. This condition is a challenge for a leader. To deal with it, a leader requires action based on the understanding of a leader. This is in line with the thought of the Greek philosopher Aritoteles about phronesis which means practical wisdom. Katangga (2019) cites (Nonaka \& Takeuchi, 2011), explaining that the conception of phronesis leadership is rooted in the theory of knowledge creation by balancing knowledge based on subjective (tacit) judgments and knowledge that can be concluded rationally clearly (explicitly). In conclusion, phronesis is knowledge that enables a person to make ethical judgments. From this phronesis theory, managers can determine 
what is good in certain times and situations to take the best course of action to realize the common good.

\section{Innovative Leadership of Local Government}

Local Government is the key to the success of the development of a region. Kaloh (2010: 43) states, as a leader, the Regional Head is a person who moves earlier, pioneers, directs the thoughts and opinions of members of the organization, guides, guides, moves others through his influence, sets organizational goals, motivates members of the organization to match the goals organization.

The granting of authority from the central government to regional governments in the era of autonomy is the entry point for the birth of various innovations at the local government level. This is where the role of the regional head is demanded to be an innovative leader, because local government innovation is a must. In addition, the competition of cities in the world is the reason for the importance of regional innovation. Zhang (2010) quoted by Noor (2017: 110) states that inter-city competition is the highest economic agenda in this millennium.

\section{METHODOLOGY}

This study uses a qualitative descriptive paradigm with a case study method in researching and analyzing the innovative leadership of regional heads in Banyuwangi with Abdullah Azwar Anas as Regent. Informants are determined purposively based on certain considerations. Primary data were obtained directly from the main informant of the Regent Abdullah Azwar Anas, while the gender data was taken from supporting documents and media reports. Triangulation informants were selected five informants who represented the State Civil Apparatus (ASN), community and religious leaders, academics, political parties and the press.

\section{RESULTS AND DISCUSSION}

\section{A. Banyuwangi and Result of Innovative Leadership}

Elected as Regent of Banyuwangi in 2010 through direct elections, Anas Regent along with his partner Yusuf Widiatmoko won 372,149 votes or 49.23 percent. (Tempo, 2019) Inaugurated on October 21, 2010, Regent Abdullah Azwar Anas kicked off the leadership by making various public sector innovations. The first year he took the lead, Regent Abdullah Azwar Anas began to collect the energy of the Banyuwangi Regency. One of them, abundant natural resources supported by cultural wealth and customs. Banyuwangi Regency has an area of 5,782.50 KM2, consisting of forest areas and agricultural land and a coastline length of $175.8 \mathrm{KM}$. The abundant natural wealth of Banyuwangi Regency is a capital for Regent Abdullah Azwar Anas to advance his region.

Education and tourism development programs are a priority in developing Banyuwangi Regency. The first year was inaugurated, Regent Abdullah Azwar Anas 
focused on making changes, especially in the tourism sector. The first year was inaugurated, Regent Azwar Anas made innovations to facilitate access to Banyuwangi. During this time, to go to Banyuwangi from the provincial capital takes about 10 hours, while from the national capital must take up to 24 hours. Conditions that are very difficult for tourists to visit. Finally, Armed with the experience of being a member of the Indonesian House of Representatives in charge of transportation, Regent Abdullah Azwar Anas made a breakthrough to open flights from Surabaya - Banyuwangi PP and Denpasar - Banyuwangi PP through Blimbingsari Airport. The airport, which was built in the era of Regent Ratna Ani Lestari in 2005, was stalled for a long time. Had gotten pessimistic action, a flight that uses a small aircraft type Grand Caravan with a capacity of 9 people was apparently able to suck up the public interest using this air transportation. The flight from Banyuwangi-Surabaya PP and Banyuwangi-Denpasar $\mathrm{PP}$ is a new entrance for tourists who come to Banyuwangi. The development of this airport continues to open flight routes to Jakarta in 2018 and flights to Malaysia in 2019.

Support with natural and cultural resources, Anas Regent made an innovation in the field of tourism in the form of the Banyuwangi Festival. The first year, the event for the promotion of this tour only held five festivals. Among them, Banyuwangi Etchno Carnival (BEC), Gandrung Sewu, International Tour de Banyuwangi Ijen (ITDBI) and Kuwung Festival (Pelangi Budaya). Remarkably, the high cost of the Banyuwangi Festival is not fully funded by the Regional Budget. Using the concept of public private partnership, the Banyuwangi Regency Government is able to hold a variety of stunning festival events. This innovation in tourism has gained recognition at national and international levels. National Level, in 2018, the Ministry of Tourism of the Republic of Indonesia has set Banyuwangi as a city of carnivals and festivals. Thus, success draws the attention of tourists. At the international level, Banyuwangi District won an international award from the United Nations Tourism Organization (UNWTO), in 2017 in the category of Awards for Excellence and Innovation in Tourism. This success was thanks to Public Policy Innovation and Tourism Governance. This achievement was able to defeat the nominees from Colombia, Kenya and Puerto Rico. The prestigious award for tourism innovation also came from the ASEAN level through the "ASEAN Tourism Forum" in Thailand, 2018 with the category "Clean Tourist City".

Innovation also targets various programs. Starting from the concern of the many babies born who have to wait long to get a birth certificate. This challenge made Regent Abdullah Azwar Anas innovate in the public sector. As pronesist leadership theory proposed by Aristotle quoted by Katangga (2019). A leader will face situations that are dilemma, ambiguous and shocking, so it is necessary to take practical wisdom. In 2013, Regent Abdullah Anas brought up an innovation with the name "Born Procot Return Bring Deed (LPPBA)", which means when a baby is born, automatically gets a deed when his parents take care of it with complete requirements. In an international forum, the innovation Born Procot Pulang Bring the Deed won a gold award at the "International Convention on Quality Control Circles (ICQCC)" in Manila, Philippines, 2017. Next, in 2014, public sector innovation in the health sector emerged. Its name is also unique, namely: Warriors of Pregnant Women Hunters which are spelled out in 
the jargon of SAKINA (Laskar Stop Maternal and Child Mortality). This innovation departs from concern with the condition of maternal and infant mortality rates in Banyuwangi Regency. This program involves health cadres in the Sempu Community Health Center who come from community participation. One of them, involving traveling vegetable traders. This innovation was named "The Most Interested Innovation" in the Asia-Pacific Open Government Partnership (GOP) forum in Seoul, South Korea, in 2018. Public sector innovation continues to be augmented by utilizing transportation technology. Namely, the innovation program of the Anticipating Cluster Long Line with Drug Delivery to Patients' Homes (Gancang Aron) which was implemented in 2017. This innovation is quite spectacular. The form, utilizing the application of modern technology in public services. This innovation was carried out to facilitate the public to enjoy health services in Blambangan Hospital, Banyuwangi.

Almost every year, there are new innovations that appear in accordance with the innovative concept, which is doing renewal. In 2016, the development of information technology, made Regent Abdullah Azwar Anas utilize digital technology to innovate the public sector down to the village level. Namely, make innovation in the form of "Smart Village" and "E-Government". This public sector innovation utilizes internet technology that is developing today. Through the internet, Regent Abdullah Azwar Anas's public services are connected from the district to village level.

Public sector innovation that was quite popular during the leadership of Regent Abdullah Azwar Anas was the creation of a Public Service Mall (MPP). This innovation is regulated in Perbup Number 59 of 2017 concerning Implementation of Public Service Malls. Although the idea of a Public Service Mall is not the first in Indonesia, the Public Service Mall at the district level is the first one that belongs to Banyuwangi. Beginning in operation, December 2017, the Public Service Mall owned by Banyuwangi Regency Government directly serves 51 public administration services. In less than a year, the administrative services provided have reached 199 types of services under one roof, starting with population administration, such as birth and death certificates, child identity cards, KTP, various types of business licenses, BPJS Health, BPJS Employment, PDAM, vehicle permit services, until the payment of regional fees. Including, marriage administration services from the Ministry of Religion to making passports and administrative registration services for prospective migrant workers. This innovation in the form of Public Service Malls received a prestigious award from the Ministry of Empowerment of the State Apparatus and Bureaucratic Reform (Kemenpan-RB) in 2018.

\section{B. Local Political Management and Bureaucracy through Transformational and Transactional Leadership}

Since the reformation in 1998, political conditions in Banyuwangi have always been turbulent. This political turbulence disappeared in the era of the leadership of Regent Abdullah Azwar Anas who was elected through a direct election, October 2010. At that time, Regent Abdullah Azwar was supported by major political parties in the 
Banyuwangi DPRD, respectively: PDIP, PKB, Golkar, PKS and PKNU. Pairing up with Yusuf Widiatmoko, Regent Abdullah Azwar Anas earned 49.23 percent of the vote.

In this study, researchers found new findings in key success factors and obstacles in realizing innovative leadership in Banyuwangi Regency. In the beginning, researchers used Mulgan \& Albury's theory as quoted by Muluk, which became the foundation for the public sector innovation process. In this theory the key to the success of innovation is not only on the leadership factor. However, in this study, more deeply known that one of the keys to the success of innovative leaders is being able to establish communication with political parties and community components, and have a detailed attitude to the ranks of the organization. This was demonstrated by Regent Abdullah Azwar Anas in establishing communication with political parties and bureaucratic management in Banyuwangi Regency. Good communication between the executive and the legislative branch makes political dynamics in Banyuwangi muted. As a result, budget discussions in the regional budget are never delayed every year. This condition makes the use of local budgets to the community can be carried out according to schedule. Meanwhile, in managing the bureaucracy, Regent Abdullah Azwar Anas adopted a detailed attitude as a leader, where his party always monitored the slightest development of innovation charged to the bureaucratic ranks. Thus, the bureaucracy is really motivated and feels supervised to participate in innovation. The program evaluation process that has been launched is also carried out routinely, so that there is no gap for bureaucratic ranks to neglect the tasks and programs that have been imposed on them.

In this study, researchers found new findings in key success factors and obstacles in realizing innovative leadership in Banyuwangi Regency. In the beginning, researchers used Mulgan \& Albury's theory as quoted by Muluk, who became the foundation for the public sector innovation process. In this theory, the key to the success of innovation is not only on the leadership factor. However, in this study, more deeply known that one of the keys to the success of innovative leaders is being able to establish communication with political parties and community components, and have a detailed attitude to the ranks of the organization. This was demonstrated by Regent Abdullah Azwar Anas in establishing communication with political parties and bureaucratic management in Banyuwangi Regency. Good communication between the executive and the legislative branch makes political dynamics in Banyuwangi muted. As a result, budget discussions in the regional budget are never delayed every year. This condition makes the use of local budgets to the community can be carried out according to the schedule. Meanwhile, in managing the bureaucracy, Regent Abdullah Azwar Anas adopted a detailed attitude as a leader, where his party always monitored the slightest development of innovation charged to the bureaucratic ranks. Thus, the bureaucracy is really motivated and feels supervised to participate in innovation. The program evaluation process that has been launched is also carried out routinely, so that there is no gap for bureaucratic ranks to neglect the tasks and programs that have been imposed on them. 


\section{The Secret of Innovative Leadership in Publik Sector}

Being an innovative leader, Regent Abdullah Azwar Anas has always focused on delivering various innovations in the public sector in Banyuwangi Regency. The figure of the Regent Abdullah Azwar Anas has a special character in leading, so that many public sector innovations are raised and lead to the birth of innovative leaders. In this study, researchers found that innovations that are usually carried out by private organizations, can be implemented well in public sector organizations. This requires the character of a leader who encourages the birth of innovation in the public sector. The research also found the innovative leader character possessed by Regent Abdullah Azwar Anas because it was driven by several factors, each: having a strong network, allergic to criticism, being able to manage politics well and being authoritatively positive.

A strong network of Abdullah Azwar Anas was obtained from his long experience in organizing. The organizational experience possessed by Regent Abdullah Azwar Anas became a strong capital for making innovative policies while serving as regional head. The experience of organizing provides a boost of knowledge for Regent Abdullah Azwar Anas to utilize his network, so that he can become an innovative leader. This is in line with the concept of leadership phronesis, where a leader with his experience will make policies for the common good when faced with an ambiguous and uncertain atmosphere. (Katangga, 2019).

The experience possessed by Abdullah Azwar Anas was able to make him give birth to policies because of the conditions he experienced while leading the Banyuwangi Regency. Such an innovation: Born Procot Pulang Bring Deed, Banyuwangi Festival and Smart Kampung which is the answer to the real needs of the people of Banyuwangi Regency.

Experience also shapes the innovative leadership character of Regent Abdullah Azwar Anas in implementing the concepts of transformational leadership and transactional leadership. As the opinion of Judge \& Piccolo (2004) and Howell \& Avolio (1993) which states that transformational leadership and transactional leadership will lead to the birth of innovative leaders in organizations. The experience possessed by Regent Abdullah Azwar Anas can reduce political and bureaucratic turbulence in Banyuwangi Regency with transformational and transactional styles.

The strong network of organizational experience owned by Regent Abdullah Azwar Anas was also able to form a strong impetus in giving birth to public sector innovation. This owned network is combined by Regent Abdullah Azwar Anas with the resources owned by Banyuwangi Regency, both human and natural resources. All of these resources were combined by Regent Abdullah Azwar Anas with the network he had gained from organizational experience. As a result, in not less than 10 years, Regent Abdullah Azwar Anas showed the development of good public sector innovation in Banyuwangi Regency. Regent Abdullah Azwar Anas also focused on the natural and cultural resources owned by Banyuwangi Regency. Thus, innovations that are driven can grow together with costs that are not too burdensome for the local budget. This is 
in line with the principle of Good Governance, which one of the facts is efficiency. (Noor. 2017)

A strong network and background of organizational experience made the leadership of Regent Abdullah Azwar Anas create a solid "wall" with the criticism movement. To bring forth innovation in the public sector, the leadership of Regent Abdullah Azwar Anas always shows an attitude of allergic criticism. The way to do this is by making a "distance" for groups who have the potential to criticize their leadership, including those who have the potential to make critical news. Thus, the news that appears in the mass media coverage tends to be positive to raise various public sector innovations that are developing in Banyuwangi Regency.

Regent Abdullah Azwar Anas's leadership, which tends to be allergic to criticism, has led to a positive attitude of an authoritarian leader. That is, Regent Abdullah Azwar Anas was able to play his role as a leader and move the components below him, in this case the bureaucracy to support the public sector innovation movement in Banyuwangi Regency.

\section{CONCLUSION}

This article tries to explain how innovative leaders emerge in the management of public sector innovation. The results showed that innovative leaders in Banyuwangi Regency were supported by a strong network because of the experience, meticulous attitude, detail and consistency of a Regional Head, as well as being able to manage the dynamics of local politics, whereby, an innovation program that was rolled out in Banyuwangi could bring this region to be known in the arena. national and international.

The ability of local government to manage the low levels of bureaucratic human resources and the ability to communicate with political parties is the key to the success of innovation in Banyuwangi. An innovative leader will always be rich in ideas, then make the atmosphere of the region free from political turbulence. So, it does not become a barrier in making innovation in the area. Good will from a leader to make changes and invite all aspects of society in the region, starting from the bureaucracy, the private sector and the community component will be the capital in implementing innovation in the area. Thus, the innovation that was rolled out was not just a discourse, but truly felt and supported by all levels of society. A leader is not only a driving force in moving the organization. However, it can be a reliable motivator and inspirator for all parts of the organization. Especially leaders as Regional Heads, as well as being a reliable marketing is the key in developing their regions.

\section{REFERENCES}

Abdul Choliq Baya. 2014. Investor, Marketer dan Kucing Garong (Dinamika Perkembangan Banyuwangi di Tangan Bupati Abdullah Azwar Anas) Banyuwangi : Nagud Publishing. 
Abdullah Azwar Anas. 2019. Anti Mainstream Marketing (20 Jurus Mengubah Banyuwangi). Jakarta: Kompas Gramedia.

Agustino, Leo. 2008. Dasar-Dasar Kebijakan Publik. Bandung: Alfabeta.

Anne E Keegan, Deanne N Den Hartog.2004. Transformational leadership in a projectbased environment: A comparative study of the leadership styles of project managers and line managers (Kepemimpinan transformasional dalam lingkungan berbasis proyek: Studi perbandingan gaya kepemimpinan manajer proyek dan manajer lini). International Journal of Project Management, Amsterdam.

Arsyad, Lincolin. 1999. Pengantar Perencanaan dan Pembangunan Ekonomi Daerah. BPFE: Yogyakarta.

Bernad M.Bass, Bruce J. Avolio. 1990. Mengembangkan Kepemimpinan Tranformasional : 1992 dan setelahnya. (Developing Transformational Leadership : 1992 and Beyond). Jornal of European Industrial Training.

Bima Katangga, 2019. Azwar Anas dan Inovasi Kepala Daerah, Studi Kepemimpinan Pronesis. International Juornal IAPA.

Building a climate for Innovation Through Transformational Leadership and Organizational Culture. Monash University dan Thomas Edison State College

Bungin, Burhan. 2011. Penelitian Kualitatif: Komunikasi, Ekonomi, Kebijakan Publik dan Ilmu Sosial Lainnya. Jakarta: Kencana.

Defni Holidin, Desy Hariyati, Eka Sri Sunarti. 2016. Reformasi Birokrasi Dalam Transisi. Jakarta : Prenada Media Grup

Dharma A. 2004. Kepemipinan yang Efektif bagi para Manajer. Bandung : Sinar Baru

Djalamudin Ancok. 2012. Psikologi Kepemimpinan dan Inovasi. Bandung : Erlangga.

Dunn, William N. 2003. Pengantar Analisis Kebijakan Publik Edisi Kedua. Gadjah Mada Univesity Press: Yogyakarta.

Eggers, W. D. and Kumar Singh, S. 2009. The Public Innovator's Playbook: Nurturing Bold Ideas in Government. Deloitte Research.

Eka Prihatin. 2011. Manajemen Peserta Didik. Bandung : Alfabeta

Greenberg J., \& Baron, R. 1995 . Behaviour in organizations. New Jersey

Hakim, Abdul Aziz. 2011. Negara Hukum dan Demokrasi. Yogyakarta: Pustaka Pelajar.

Hardiyansyah.2018. Kualitas Pelayanan Publik. Yogyakarta; Gava Media.

Howell, J. M., and Higgins, C. A. 1990 . Administrative Science Quarterly. Jurnal Champions of technological innovation.

Ignas Dzemyda, Borisas Melnikas.2009. Inovasi, Penelitian dan Pengembangan di Uni Eropa: Dampak terhadap Ekonomi Regional (Innovations, Research and Development in European Union: Impact on Regional Economy). Mykolas Romeris University, Vilnius Gediminas University.

Irwan Noor. 2017. Desain Inovasi Pemerintahan Daerah. Malang : UB Press

Islamy, Irfan. 1984. Prinsip-Prinsip Perumusan Kebijaksanaan Negara. Jakarta: Bumi Aksara.

J.Kaloh, 2010. Kepemimpinan Kepala Daerah. Jakarta: Sinar Grafika.

James C.Sarros, Brian K.Cooper, Joseph C.Santora.2008. 
James G. March and Johan P. Olson.1983. Organizing Political Life: What Administrative Reorganization Tells Us about Government. Journal : American Political Science Review

Jane M.Howell, Bruce J.Avolio.1993. Transformational leadership, Transactional Leadership, Locus of Control and Support for Innovation : Key Predictors of Consolidated Business Unit Performance). American Psychological Association.

Judge, Timothy A, Piccolo, Ronald F. 2004. (Transformational and Transactional Leadership: A Meta-Analytic Test of Their Relative Validity. Journal of Applied Psychology, Vol 89(5), Oct 2004, 755-768

K Davis, JW Newstrom. 1995. Perilaku Organisasi, Jilid I dan II, Alih Bahasa Agus Dharma. Jakarta : Erlangga

Kathrin Rosing, Michael Frese, Andreas Bausch. Explaining the heterogeneity of leadership-innovation relationship : Ambidextrous leadership. The Learship Quarterly, Germany.

Keban, Yeremias T. 2008. Enam Dimensi Strategis Administrasi Publik Konsep,Teori dan Isu. Yogyakarta: Gava Media.

Kencana, Syafiie Inu. 2006. Ilmu Administrasi Publik. Jakarta: Rineka Cipta.

Komorotomo, Wahyudi. 2003. Etika Administrasi Negara. Jakarta: Rajawali Pers.

Kountur, Roony. 2003. Metode Penelitian untuk Penulisan Skripsi dan Tesis. Jakarta: PPM.

Kouzes, J.M., \& Posner, B.Z. 2007. The Leadership Challenge. New York: John Wiley and Sons.

Kuncoro, Mudrajad. 2000. Ekonomi Pembangunan: Teori, Masalah dan Kebijakan. Yogyakarta: UPP AMP YKPN.

Kusdi. 2009. Teori Organisasi dan Birokrasi. Jakarta: Salemba Humanika.

Lale Gumuluoglu, Arzu Ilsev. 2009. Transformational leadership, creativity and organizational innovation. Bilkent University of Business Administration, Turki.

Makhya, Syarief. 2004. Ilmu Pemerintahan: Telaahan Awal (Buku Ajar), Universitas Bandar Lampung.

Mark Considine, Jenny M. Lewis, Damon Alexander.2009. Network, Innovatoins and Public Policy: Politicians, Beureaucrats and the Path Wayas to Change Inside Government. University of Melbourne, Australia

Masyri dan Zaenudin. 2009. Metodologi Penelitian (Pendekatan Praktis dan Aplikatif. Bandung : Refika Aditama.

Mathis Sculte, Cheri Ostroff, Angelo J. Kinichi. 2006. Organizational climate systems and psychological climate perceptions: A cross-level study of climate-satisfaction relationships. Journal of Occupational and Organizational Psychology,USA

Matthew B. Miles, A. Michael Huberman, Johnny Saldana. 2014. Qualitative Data Analysis, A Methods Sourcebook. SAGE Publications : USA

Moleong, Lexy J. 2012. Metodologi Penelitian Kualitatif. Bandung: PT. Remaja Rosdakarya.

Mudrajat, Kuncoro. 2002. Analisis Spasial dan Regional: Studi Aglomerasi dan Kalster Industri Indonesia. Yogyakarta: UPP AMP YKPN. 
Muhammad Aulia Fachrudin.2015. Inovasi Kepemimpinan Kepala Daerah (Studi Kasus Walikota Surabaya,Ir.Tri Rismaharini,MT). Fakultas Politik dan Ilmu Pemerintahan, Universitas Diponegoro.

Muluk, Khairul. 2008. Knowledge Management Kunci Sukses Inovasi Pemerintah Daerah. Jatim: Bayumedia Publishing.

Muluk, M.R. Khairul. 2007. Menggugat Partisipasi Publik dalam Pemerintahan Daerah (Sebuah Kajian Adminstrasi Publik dengan Pendekatan Berfikir Sistem). Malang: Bayumedia Publishing.

Mumford,MD dan Gustafson,S.B. 1998. Creativity Syndrome : Integration, Application and Innovation. Psychology Bulletin.

Mustopadidjaja, Dr. 1992. Studi Kebijaksanaan. Jakarta: Universitas Indonesia.

Nawawi.2003. Kepemimpinan Mengefektifkan Organisasi. Yogyakara : Gajah Mada University

Noor, Juliansyah. 2012. Metodologi Penelitian Skripsi Tesis Disertasi dan Karya Ilmiah. Jakarta: Kencana

Nugroho. Riant. 2012. Public Policy. Jakarta: PT. Elex Media Komputindo.

Nurmah Semil. 2018. Pelayanan Prima Instansi Pemerintah. Depok : Prenada Media Grup.

Nurzaman, S.S. 2002. Perencanaan Wilayah di Indonesia Pada Masa Sekitar Krisis. Bandung: ITB.

Pasolong, Harbani. 2008. Teori Administrasi Publik. Bandung: Alfabeta.

Prastowo, Andi. 2012. Metode Penelitian Kualitatif dalam Perspektif Rancangan Penelitian. Yogyakarta: Ar-Ruzz Media.

Purwanto, E. A. \& Sulistyastuti, D. R. 2007. Metode Penelitian Kuantitatif Untuk Administrasi Publik dan Masalah-Masalah Sosial. Jogjakarta: Gava Media.

Rivai V. 2004. Kiat Memimpin dalam Abad ke-2l. Jakarta : Raja Grafindo Persada

Santosa, Pandji. 2009. Administrasi Publik Teori dan Aplikasi Good Governance. Bandung: PT Revika Aditama.

Sjafrizal, 2008. Ekonomi Regional, Teori dan Aplikasi. Baduose Media, Cetakan Pertama. Padang.

Solichin, Abdul Wahab. 1997. Analisis Kebijaksanaan dari Formulasi ke Implementasi Kebijaksanaan Negara. Jakarta : Bumi Aksara.

Sondang PS.2003. Teori dan Praktek Kepemimpinan. Jakarta : PT. Rineka Cipta

Sri Wintala Achmad.2018. Falsafah Kepemimpinan Jawa. Yogyakarta : Araska.

Sudaryono, 2017. Metodologi Penelitian. Jakarta : Rajawali Pers

Sudaryono,2014. Leadership (Teori dan Praktik Kepemimpinan). Jakarta : Lentera Ilmu Cendikia

Sugiyono. 2011. Metode Penelitian Kuantitatif, Kualitatif, dan R\&\&D. Bandung: Alfabeta. Suwarno, Yogi. 2008. Inovasi disektor publik. Jakarta: STIA-LAN Press.

Syafiie, Inu Kencana. 2001. Pengantar Ilmu Pemerintahan. Bandung: Refika Aditama

Universitas Jember. 2012. Pedoman Penulisan Karya Tulis Ilmiah. Jember: Jember University Press. 
Usman, H. \& Akbar, P. S. 2003. Metodologi Penelitian Sosial. Jakarta: PT Bumi Aksara. Wahjosumidjo. 2002. Kepemimpinan Kepala Sekolah. Jakarta: PT Raja Grafindo Persada

Widjaja. A.W. 201l. Otonomi Daerah dan Daerah Otonom. Jakarta: PT Raja Grafindo Persada.

Winarno, Budi. 2002. Kebijakan Publik: Teori dan Proses. Media Presindo: Yogyakarta Yunitasari.2017. Kepemimpinan FX.Hadi Rudyatmo dalam Mewujudkan Solo Kota Layak Anak. Universitas Gajah Mada. 